\title{
Open Reading Frame
}

National Human Genome Research Institute (NHGRI)

\section{Source}

National Human Genome Research Institute (NHGRI). Open Reading Frame.

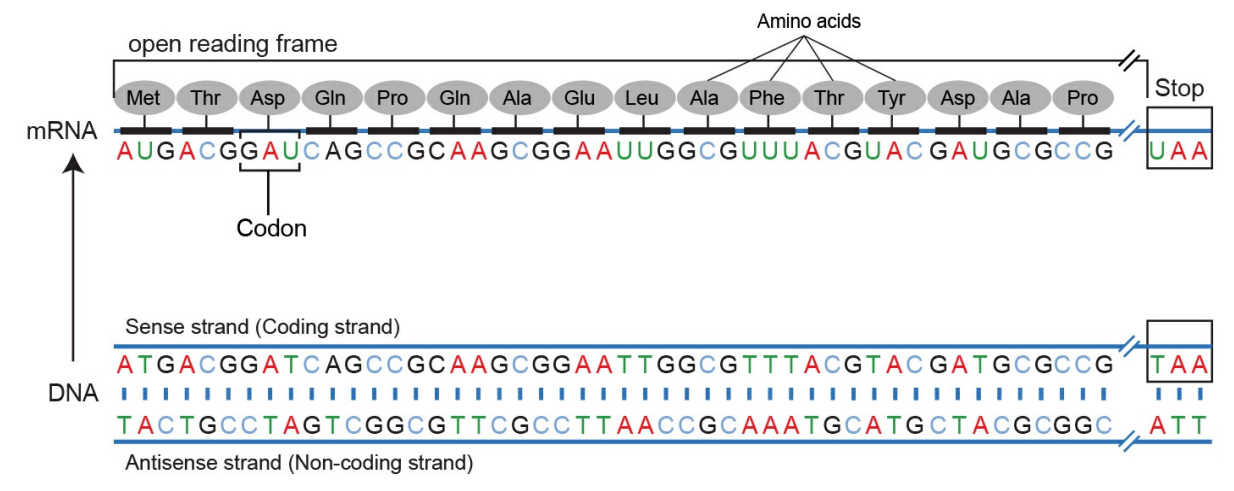

An open reading frame is a portion of a DNA molecule that, when translated into amino acids, contains no stop codons. The genetic code reads DNA sequences in groups of three base pairs, which means that a double-stranded DNA molecule can read in any of six possible reading frames--three in the forward direction and three in the reverse. A long open reading frame is likely part of a gene. 